\title{
Genetic variability of a scattered temperate forest tree: Sorbus torminalis L. (Crantz)
}

\author{
Brigitte Demesure ${ }^{\mathrm{a}, *}$, Bénédicte Le Guerrouéa ${ }^{\text {, Géraldine Lucchi }}{ }^{\mathrm{a}}$, \\ Daniel Prat ${ }^{\mathrm{b}}$ and Rémy-Jacques Petit ${ }^{\mathrm{c}}$ \\ ${ }^{a}$ Conservatoire génétique des arbres forestiers, Office National des Forêts, Campus INRA, F-45160 Ardon, France \\ ${ }^{\mathrm{b}}$ Laboratoire de génétique et amélioration des arbres forestiers, INRA, F-45160 Ardon, France \\ ${ }^{c}$ Laboratoire de génétique des arbres forestiers, INRA, BP. 45, F-33611 Gazinet Cedex, France
}

(Received 20 January 1999; accepted October 4, 1999)

\begin{abstract}
Genetic variation has been assessed in 73 (mostly French) populations of the wild service tree (Sorbus torminalis) using 15 isozymes loci. In spite of a relatively high coefficient of genetic differentiation among populations $\left(F_{\mathrm{ST}}=15 \%\right)$, only a weak geographical structure was detected. This may be explained by the small size and young age of the populations due to the importance of founder effects, combined with the high levels of seed flow among populations. These features are typical of species characterised by metapopulation dynamics.
\end{abstract}

genetic diversity / differentiation / metapopulation / Rosaceae / spatial structure

Résumé - Variabilité génétique d'une espèce forestière disséminée : Sorbus torminalis L. (Crantz). De nombreuses études se sont intéressées à la diversité génétique des plantes rares, menacées de disparition, ou à celles largement répandues qui présentent un grand intérêt économique. Par contre, le cas des espèces ayant une aire de répartition importante mais présentant des densités faibles reste peu abordé, en particulier chez les arbres forestiers. Dans les forêts tempérées, les arbres forestiers disséminés occupent une place secondaire. L'alisier torminal (Sorbus torminalis) est une espèce fruitière disséminée au comportement post-pionnier nomade. Ses graines sont dispersées par les oiseaux. 67 populations françaises et 6 populations d'Europe centrale ont été étudiées à l'aide des isozymes. Une forte différentiation entre populations a été trouvée $\left(F_{\mathrm{ST}}=15 \%\right)$, combinée à une faible structuration géographique. Ceci peut s'expliquer par les effets de fondation importants liés au comportement écologique de l'espèce, et aux flux de graines entre populations éloignées, liés à la dissémination par des oiseaux. Le modèle en métapopulation, avec des populations subissant des phénomènes de colonisation et d'extinction, mais restant interconnectées par des flux de gènes, semble particulièrement bien s'appliquer à cette espèce. Au vu de ces résultats, une gestion permettant l'implantation de l'alisier dans de nouveaux sites pouvant recevoir des flux de gènes des populations préexistantes doit être encouragée.

Rosaceae / diversité génétique / métapopulation / differentiation / structure spatiale

\section{INTRODUCTION}

Since the development of isozyme markers, thousands of population genetic studies of wild plants, including a large proportion dealing with forest trees, have been carried out either in temperate or in tropical regions. These studies have pointed out the importance of the size of the geographic range of the species for predicting levels and organisation of genetic diversity: in general, species with widespread distributions maintain higher levels of genetic diversity at allozyme loci than species with narrow or endemic distribution [10,

* Correspondence and reprints

demesure@orleans.inra.fr 
11, 32]. Similarly, allozyme surveys have shown that geographically restricted species that are locally abundant contain fewer polymorphic loci and a lower mean number of alleles per locus than widespread congeneric species $[14,15]$. The importance of the size of the population has also been investigated for a more limited number of plant species. These studies have shown that common species with large population sizes are more variable than rare species [37]. However, little is known about trees with widespread distribution but having low population densities, i.e. between 0.1 and 30 adults by hectare. This lack of knowledge is due first to the low economic impact of these species compared to social forest trees such as Quercus spp. or Picea abies in Europe and second to the difficulty to inventory them. Yet the scattered trees contribute to increase the biodiversity of the forest, by their presence but also because many animal species rely on them.

Nevertheless, some results concerning genetic diversity of disseminated trees based on enzymes have started to appear recently both in temperate countries [22, 30, $33,40]$ as well as in tropical ones [4, 15, 37]. These species generally show lower genetic diversity than widespread species. But comparisons with more abundant species are difficult, because sampling of scattered species often involves few populations with limited sample sizes per population. Here, we present the results of an investigation of the genetic variability of a scattered tree species, the wild service tree, Sorbus torminalis (L.) Crantz, based on an intensive sampling of populations in France. This member of the Rosaceae family is one of the most economically important wild fruit trees in Europe. It is a scattered species ( 0.1 to 30 adults per hectare) which never occurs in pure populations. It grows on all types of soils. It is a post-pioneer tree that colonises disturbed areas and forest edges. Although the trees are generally overgrown by more competitive species such as Quercus or Fagus [5], individual trees can be very valuable when they benefit from good soil and light conditions. Sorbus torminalis is a diploid species $(2 n=34)$ according to Liljefors [20]. This species is insect pollinated and the seeds are dispersed by birds. A recent study on Sorbus commixta in Japan [45] reports that extraction of seeds from the pulp is necessary for their germination. Sorbus torminalis is also able to propagate asexually through the production of suckers. The natural distribution of Sorbus torminalis is rather large, from the north of Magrehb to the south of Sweden and from the east of Great Britain to the north of Iran. It grows mostly in lowlands. In France, the most important populations of Sorbus torminalis are located in the south-west and in the north-east of the country. Hybridisation with other Sorbus species, especially with
Sorbus aria, another diploid species, is considered to be frequent in Europe [9].

\section{MATERIALS AND METHODS}

\subsection{Materials}

Sixty seven indigenous populations of Sorbus torminalis were sampled in France (figure 1). The collection also included six populations originating from other countries in Europe: Slovakia (3 populations), Slovenia, Bulgaria, and Switzerland (one population each) (table I). A population sample consists of dormant buds from at least 11 mature trees or young stems separated from each other by at least $50 \mathrm{~m}$ (to avoid sampling the same clone) on an area of 20 to 50 ha. In such conditions the sampling of individuals may or not be exhaustive, depending on the local density. To allow comparisons among regions, French populations were grouped according to their geographical proximity. Several geographical clustering of populations were tested. The results of gene diversity and differentiation were very similar. The final choice (eight groups) resulted from a compromise between homogeneous number of populations per group and geographical proximity (figure 1).

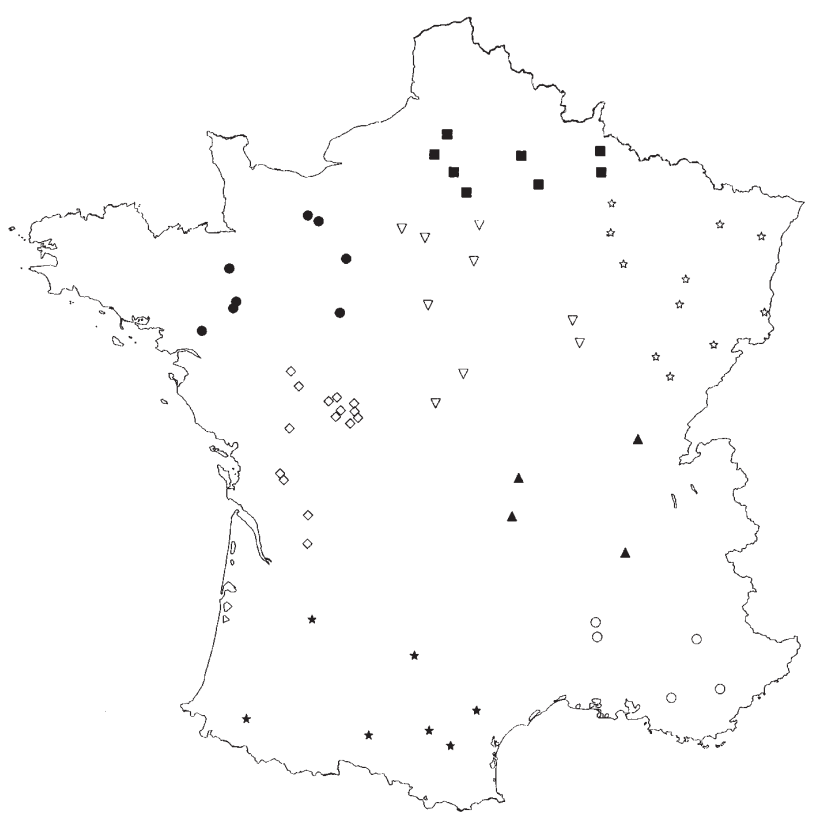

Fig.1. Geographical distribution of populations of Sorbus torminalis. Populations were clustered in 8 groups according to their geographical proximity. Symbols for the groups are group 1 group $2 \nabla$, group $3 \bullet$, group $4 \diamond$, group $5 \star$, group $6 \bigcirc$, group $7 \boldsymbol{\Delta}$, group 8 㲾. 
Table I. Geographic origin, and genetic diversity estimates and inbreeding coefficient (based on 15 allozyme loci) for 73 populations of Sorbus torminalis.

$N_{\mathrm{a}}$, number of alleles per locus; $H_{\mathrm{o}}$, observed heterozygosity; $H_{\mathrm{e}}$, expected heterozygosity; $F_{\text {IS }}$, heterozygote deficit.

\begin{tabular}{|c|c|c|c|c|c|c|c|c|}
\hline Populations & Longitude & Lattitude & Groups & Sample size & $N_{\mathrm{a}}$ & $H_{\mathrm{o}}$ & $H_{\mathrm{e}}$ & $F_{\text {IS }}$ \\
\hline Assenoncourt & $06^{\circ} 45^{\prime} \mathrm{E}$ & $48^{\circ} 47^{\prime} \mathrm{N}$ & 8 & 21 & 1.600 & 0.116 & 0.151 & 0.232 \\
\hline Aulnay & $00^{\circ} 28^{\prime} \mathrm{E}$ & $46^{\circ} 00^{\prime} \mathrm{N}$ & 4 & 19 & 1.733 & 0.175 & 0.179 & 0.022 \\
\hline Avants Monts & $02^{\circ} 41^{\prime} \mathrm{E}$ & $43^{\circ} 26^{\prime} \mathrm{N}$ & 5 & 12 & 1.333 & 0.100 & 0.080 & -0.250 \\
\hline Bellême & $00^{\circ} 31^{\prime} \mathrm{E}$ & $48^{\circ} 24^{\prime} \mathrm{N}$ & 3 & 11 & 1.533 & 0.145 & 0.164 & 0.116 \\
\hline Bercé & $05^{\circ} 02^{\prime} \mathrm{E}$ & $45^{\circ} 08^{\prime} \mathrm{N}$ & 3 & 18 & 1.667 & 0.130 & 0.175 & 0.257 \\
\hline Bois rogue & $00^{\circ} 13^{\prime} \mathrm{W}$ & $46^{\circ} 59^{\prime} \mathrm{N}$ & 4 & 20 & 1.600 & 0.105 & 0.173 & 0.393 \\
\hline Bourdogne & $00^{\circ} 25^{\prime} \mathrm{E}$ & $47^{\circ} 48^{\prime} \mathrm{N}$ & 7 & 20 & 1.800 & 0.157 & 0.197 & 0.203 \\
\hline Bourg St Andéol & $04^{\circ} 34^{\prime} \mathrm{E}$ & $44^{\circ} 25^{\prime} \mathrm{N}$ & 6 & 18 & 1.600 & 0.126 & 0.135 & 0.067 \\
\hline Braconne & $00^{\circ} 20^{\prime} \mathrm{W}$ & $46^{\circ} 30^{\prime} \mathrm{N}$ & 4 & 20 & 1.600 & 0.149 & 0.169 & 0.118 \\
\hline Byans sur le Doubs & $05^{\circ} 49^{\prime} \mathrm{E}$ & $47^{\circ} 05^{\prime} \mathrm{N}$ & 8 & 19 & 1.533 & 0.128 & 0.120 & -0.067 \\
\hline Canjuers & $06^{\circ} 25^{\prime} \mathrm{E}$ & $43^{\circ} 38^{\prime} \mathrm{N}$ & 6 & 20 & 1.533 & 0.135 & 0.153 & 0.118 \\
\hline Chantilly & $02^{\circ} 29^{\prime} \mathrm{E}$ & $49^{\circ} 10^{\prime} \mathrm{N}$ & 1 & 20 & 1.800 & 0.186 & 0.200 & 0.070 \\
\hline Charve Chave & $03^{\circ} 22^{\prime} \mathrm{E}$ & $46^{\circ} 00^{\prime} \mathrm{N}$ & 7 & 19 & 1.667 & 0.116 & 0.150 & 0.227 \\
\hline Chatrices & $04^{\circ} 57^{\prime} \mathrm{E}$ & $49^{\circ} 01^{\prime} \mathrm{N}$ & 8 & 14 & 1.733 & 0.177 & 0.201 & 0.119 \\
\hline Chillou & $00^{\circ} 39^{\prime} \mathrm{E}$ & $46^{\circ} 35^{\prime} \mathrm{N}$ & 4 & 20 & 1.733 & 0.137 & 0.186 & 0.263 \\
\hline Chizé & $00^{\circ} 17^{\prime} \mathrm{W}$ & $46^{\circ} 03^{\prime} \mathrm{N}$ & 4 & 20 & 1.733 & 0.137 & 0.230 & 0.404 \\
\hline Choeurs Bommiers & $02^{\circ} 00^{\prime} \mathrm{E}$ & $46^{\circ} 51^{\prime} \mathrm{N}$ & 2 & 21 & 1.600 & 0.139 & 0.202 & 0.312 \\
\hline Chouanière & $01^{\circ} 21^{\prime} \mathrm{W}$ & $47^{\circ} 53^{\prime} \mathrm{N}$ & 3 & 20 & 1.667 & 0.143 & 0.152 & 0.059 \\
\hline Claix & $00^{\circ} 02^{\prime} \mathrm{E}$ & $45^{\circ} 32^{\prime} \mathrm{N}$ & 4 & 20 & 1.600 & 0.113 & 0.146 & 0.226 \\
\hline Corbières Occidentales & $02^{\circ} 17^{\prime} \mathrm{E}$ & $43^{\circ} 02^{\prime} \mathrm{N}$ & 5 & 23 & 1.733 & 0.142 & 0.160 & 0.113 \\
\hline Croix aux bois & $04^{\circ} 47^{\prime} \mathrm{E}$ & $49^{\circ} 18^{\prime} \mathrm{N}$ & 1 & 20 & 1.533 & 0.107 & 0.127 & 0.157 \\
\hline Crugny & $03^{\circ} 44^{\prime} \mathrm{E}$ & $49^{\circ} 16^{\prime} \mathrm{N}$ & 1 & 19 & 1.467 & 0.123 & 0.147 & 0.163 \\
\hline Dreux & $01^{\circ} 23^{\prime} \mathrm{E}$ & $48^{\circ} 46^{\prime} \mathrm{N}$ & 2 & 20 & 1.667 & 0.133 & 0.161 & 0.174 \\
\hline Ferrières & $02^{\circ} 43^{\prime} \mathrm{E}$ & $48^{\circ} 500^{\prime} \mathrm{N}$ & 2 & 26 & 1.600 & 0.120 & 0.164 & 0.268 \\
\hline Fontainebleau & $02^{\circ} 37^{\prime} \mathrm{E}$ & $48^{\circ} 25^{\prime} \mathrm{N}$ & 2 & 18 & 1.447 & 0.095 & 0.093 & -0.022 \\
\hline Fossemanant & $02^{\circ} 08^{\prime} \mathrm{E}$ & $49^{\circ} 49^{\prime} \mathrm{N}$ & 1 & 22 & 1.667 & 0.144 & 0.170 & 0.153 \\
\hline Gardiole & $05^{\circ} 41^{\prime} \mathrm{E}$ & $43^{\circ} 34^{\prime} \mathrm{N}$ & 6 & 19 & 1.600 & 0.126 & 0.122 & -0.033 \\
\hline Gatinalière & $00^{\circ} 20^{\prime} \mathrm{E}$ & $46^{\circ} 59^{\prime} \mathrm{N}$ & 4 & 21 & 1.600 & 0.169 & 0.152 & -0.112 \\
\hline Gâvre & $01^{\circ} 50 \prime \mathrm{W}$ & $47^{\circ} 31^{\prime} \mathrm{N}$ & 3 & 20 & 1.667 & 0.157 & 0.165 & 0.048 \\
\hline Gouffern & $00^{\circ} 01^{\prime} \mathrm{W}$ & $48^{\circ} 49^{\prime} \mathrm{N}$ & 3 & 20 & 1.800 & 0.155 & 0.181 & 0.144 \\
\hline Grand Vallon & $06^{\circ} 04^{\prime} \mathrm{E}$ & $44^{\circ} 11^{\prime} \mathrm{N}$ & 6 & 13 & 1.467 & 0.082 & 0.119 & 0.311 \\
\hline Grésigne & $01^{\circ} 44^{\prime} \mathrm{E}$ & $44^{\circ} 02^{\prime} \mathrm{N}$ & 5 & 15 & 1.600 & 0.132 & 0.160 & 0.175 \\
\hline Guerche & $01^{\circ} 14^{\prime} \mathrm{W}$ & $47^{\circ} 52^{\prime} \mathrm{N}$ & 3 & 20 & 1.733 & 0.133 & 0.168 & 0.208 \\
\hline Gurs & $00^{\circ} 48^{\prime} \mathrm{W}$ & $43^{\circ} 15^{\prime} \mathrm{N}$ & 5 & 15 & 1.667 & 0.129 & 0.143 & 0.098 \\
\hline Harth & $07^{\circ} 23^{\prime} \mathrm{E}$ & $47^{\circ} 46^{\prime} \mathrm{N}$ & 8 & 20 & 1.800 & 0.234 & 0.223 & -0.049 \\
\hline Hez Froidemont & $02^{\circ} 16^{\prime} \mathrm{E}$ & $49^{\circ} 24^{\prime} \mathrm{N}$ & 1 & 20 & 1.733 & 0.147 & 0.142 & -0.035 \\
\hline Hospice de Chalais & $00^{\circ} 04^{\prime} \mathrm{W}$ & $45^{\circ} 14^{\prime} \mathrm{N}$ & 4 & 20 & 1.600 & 0.137 & 0.132 & -0.038 \\
\hline Hurecourt & $06^{\circ} 02^{\prime} \mathrm{E}$ & $47^{\circ} 55^{\prime} \mathrm{N}$ & 8 & 12 & 1.533 & 0.162 & 0.164 & 0.012 \\
\hline Isle s/le Doubs & $06^{\circ} 34^{\prime} \mathrm{E}$ & $47^{\circ} 26^{\prime} \mathrm{N}$ & 8 & 18 & 1.667 & 0.141 & 0.188 & 0.250 \\
\hline Le Plan & $01^{\circ} 05^{\prime} \mathrm{E}$ & $43^{\circ} 08^{\prime} \mathrm{N}$ & 5 & 12 & 1.600 & 0.106 & 0.150 & 0.293 \\
\hline Liffré & $01^{\circ} 28^{\prime} \mathrm{W}$ & $48^{\circ} 13^{\prime} \mathrm{N}$ & 3 & 20 & 1.667 & 0.103 & 0.144 & 0.285 \\
\hline Malmifait & $01^{\circ} 56^{\prime} \mathrm{E}$ & $49^{\circ} 35^{\prime} \mathrm{N}$ & 1 & 20 & 1.600 & 0.144 & 0.156 & 0.077 \\
\hline Mareuil & $00^{\circ} 31^{\prime} \mathrm{E}$ & $46^{\circ} 34^{\prime} \mathrm{N}$ & 4 & 17 & 1.733 & 0.170 & 0.191 & 0.110 \\
\hline Mas d'agenais & $00^{\circ} 09^{\prime} \mathrm{E}$ & $44^{\circ} 24^{\prime} \mathrm{N}$ & 5 & 22 & 1.533 & 0.123 & 0.156 & 0.212 \\
\hline Montceau & $04^{\circ} 21^{\prime} \mathrm{E}$ & $47^{\circ} 29^{\prime} \mathrm{N}$ & 2 & 13 & 1.600 & 0.122 & 0.161 & 0.242 \\
\hline Mouliére & $00^{\circ} 32^{\prime} \mathrm{E}$ & $46^{\circ} 49^{\prime} \mathrm{N}$ & 4 & 19 & 1.667 & 0.221 & 0.186 & -0.188 \\
\hline Nanc les St Amour & $05^{\circ} 17^{\prime} \mathrm{E}$ & $46^{\circ} 25^{\prime} \mathrm{N}$ & 7 & 13 & 1.467 & 0.154 & 0.142 & -0.085 \\
\hline Orléans & $01^{\circ} 52^{\prime} \mathrm{E}$ & $47^{\circ} 56^{\prime} \mathrm{N}$ & 2 & 21 & 1.533 & 0.083 & 0.185 & 0.551 \\
\hline Pleumartin & $00^{\circ} 52^{\prime} \mathrm{E}$ & $46^{\circ} 37^{\prime} \mathrm{N}$ & 4 & 19 & 1.667 & 0.155 & 0.173 & 0.104 \\
\hline Puygareau & $00^{\circ} 17^{\prime} \mathrm{E}$ & $46^{\circ} 50^{\prime} \mathrm{N}$ & 4 & 22 & 1.667 & 0.144 & 0.197 & 0.269 \\
\hline Rambouillet & $01^{\circ} 47^{\prime} \mathrm{E}$ & $48^{\circ} 40^{\prime} \mathrm{N}$ & 2 & 21 & 1.667 & 0.125 & 0.163 & 0.233 \\
\hline Ravières & $04^{\circ} 16^{\prime} \mathrm{E}$ & $47^{\circ} 44^{\prime} \mathrm{N}$ & 2 & 22 & 1.800 & 0.128 & 0.189 & 0.323 \\
\hline Roche de bran & $00^{\circ} 28^{\prime} \mathrm{E}$ & $46^{\circ} 42^{\prime} \mathrm{N}$ & 4 & 20 & 1.667 & 0.153 & 0.173 & 0.116 \\
\hline Roche posay & $00^{\circ} 44^{\prime} \mathrm{E}$ & $46^{\circ} 47^{\prime} \mathrm{N}$ & 4 & 19 & 1.667 & 0.151 & 0.162 & 0.068 \\
\hline Rouvroy sur Marne & $05^{\circ} 29^{\prime} \mathrm{E}$ & $48^{\circ} 23^{\prime} \mathrm{N}$ & 8 & 20 & 1.600 & 0.173 & 0.170 & -0.018 \\
\hline St André & $00^{\circ} 13^{\prime} \mathrm{W}$ & $48^{\circ} 52^{\prime} \mathrm{N}$ & 3 & 20 & 1.533 & 0.097 & 0.131 & 0.260 \\
\hline
\end{tabular}


Table I. Continued.

\begin{tabular}{lccccccrr}
\hline Populations & Longitude & Lattitude & Groups & Sample size & $N_{\mathrm{a}}$ & $H_{\mathrm{o}}$ & $H_{\mathrm{e}}$ & $F_{\text {IS }}$ \\
\hline St Babel & $03^{\circ} 16^{\prime} \mathrm{E}$ & $45^{\circ} 34^{\prime} \mathrm{N}$ & 7 & 14 & 1.533 & 0.167 & 0.150 & -0.113 \\
St Gobain & $03^{\circ} 50^{\prime} \mathrm{E}$ & $49^{\circ} 35^{\prime} \mathrm{N}$ & 1 & 11 & 1.467 & 0.061 & 0.134 & 0.545 \\
St Vallier & $06^{\circ} 08^{\prime} \mathrm{E}$ & $48^{\circ} 10^{\prime} \mathrm{N}$ & 8 & 24 & 1.667 & 0.127 & 0.175 & 0.274 \\
Ternay & $00^{\circ} 21^{\prime} \mathrm{W}$ & $47^{\circ} 08^{\prime} \mathrm{N}$ & 4 & 20 & 1.533 & 0.114 & 0.140 & 0.186 \\
Trois Fontaines & $04^{\circ} 55^{\prime} \mathrm{E}$ & $48^{\circ} 46^{\prime} \mathrm{N}$ & 8 & 14 & 1.600 & 0.178 & 0.192 & 0.073 \\
Valay & $05^{\circ} 38^{\prime} \mathrm{E}$ & $47^{\circ} 20^{\prime} \mathrm{N}$ & 8 & 30 & 1.533 & 0.151 & 0.151 & 0.000 \\
Valbonne & $04^{\circ} 34^{\prime} \mathrm{E}$ & $44^{\circ} 16^{\prime} \mathrm{N}$ & 6 & 19 & 1.467 & 0.086 & 0.120 & 0.283 \\
Vendresse & $04^{\circ} 46^{\prime} \mathrm{E}$ & $49^{\circ} 37^{\prime} \mathrm{N}$ & 1 & 16 & 1.733 & 0.154 & 0.166 & 0.072 \\
Vierzon & $02^{\circ} 27^{\prime} \mathrm{E}$ & $47^{\circ} 10^{\prime} \mathrm{N}$ & 2 & 21 & 1.467 & 0.095 & 0.118 & 0.195 \\
Villasavary & $01^{\circ} 59^{\prime} \mathrm{E}$ & $43^{\circ} 13^{\prime} \mathrm{N}$ & 5 & 15 & 1.533 & 0.102 & 0.090 & -0.133 \\
Wasselone & $07^{\circ} 25^{\prime} \mathrm{E}$ & $48^{\circ} 36^{\prime} \mathrm{N}$ & 8 & 11 & 1.467 & 0.108 & 0.113 & 0.044 \\
Central Europe & & & & & & & \\
Bulgarie & $27^{\circ} 05^{\prime} \mathrm{E}$ & $43^{\circ} 18^{\prime} \mathrm{N}$ & $\mathrm{EC}$ & 20 & 1.733 & 0.105 & 0.117 & 0.103 \\
Slovaquie 1 & $21^{\circ} 36^{\prime} \mathrm{E}$ & $49^{\circ} 07^{\prime} \mathrm{N}$ & $\mathrm{EC}$ & 42 & 1.667 & 0.070 & 0.100 & 0.300 \\
Slovaquie 2 & $19^{\circ} 18^{\prime} \mathrm{E}$ & $48^{\circ} 30^{\prime} \mathrm{N}$ & $\mathrm{EC}$ & 34 & 1.800 & 0.152 & 0.139 & -0.094 \\
Slovaquie 3 & $21^{\circ} 03^{\prime} \mathrm{E}$ & $48^{\circ} 48 \mathrm{~N}$ & $\mathrm{EC}$ & 65 & 1.800 & 0.127 & 0.143 & 0.112 \\
Slovénie & $13^{\circ} 26^{\prime} \mathrm{E}$ & $45^{\circ} 16^{\prime} \mathrm{N}$ & $\mathrm{EC}$ & 29 & 1.600 & 0.123 & 0.122 & -0.008 \\
Suisse & $09^{\circ} 04^{\prime} \mathrm{E}$ & $45^{\circ} 30^{\prime} \mathrm{N}$ & $\mathrm{EC}$ & 86 & 1.800 & 0.152 & 0.179 & 0.151 \\
\hline
\end{tabular}

\subsection{Electrophoresis}

The buds sampled ( 3 to 5 per tree) were ground in a cooled mortar containing the protein extraction buffer (360 $\mu \mathrm{L}$ for $200 \mathrm{mg}$ of plant material), which was a Tris$\mathrm{HCl}$ buffer $(0.02 \mathrm{M}, \mathrm{pH}=7.6)$ supplemented with $1.0 \%$ bovine serum albumin, $2 \%$ polyethyleneglycol $8000,1 \%$ dithiothreitol, $14 \mu \mathrm{M} \beta$-mercaptoethanol. The homogenates were centrifuged at $15000 \mathrm{~g}$ for $20 \mathrm{~min}$ at $4{ }^{\circ} \mathrm{C}$. The extracts were stored at $-80{ }^{\circ} \mathrm{C}$ until analysis. The electrophoretic migration took place at $4{ }^{\circ} \mathrm{C}$ in horizontal starch gels under an electric field of $80 \mathrm{mV} \mathrm{cm}^{-1}$ for one night.

Of the 18 enzyme systems tested (some were tested with various substrates and staining procedures) the following 11 were finally retained because of the reproducible patterns and of the straightforward genetic interpretations: $A A P$, E.C. 3.4.11.1 (alanine aminopeptidase, one locus: $A A P-1$ ), $A C P$, E.C. 3.1.3.2 (acid phospatase, one locus: $A C P-1$ ), $A D H$, E.C. 1.1.1.1 (alcohol dehydrogenase, one locus: $A D H-1), G O T$, E.C. 2.6.1.1 (glutamate oxaloacetate transaminase, one locus: GOT-2), IDH, E.C. 1.1.1.42 (isocitrate dehydrogenase, two loci: $I D H-1, I D H-2), P R X$, E.C. 1.11.1.7 (peroxidase, two loci: $P R X-1, P R X-2$ ), $M E$ E.C. 1.1.1.40 (malic enzyme, one locus: $M E-1$ ), $M R$ E.C. 1.6.99.2 (menadione reductase, two loci: $M R-1, M R-2), P G M$, E.C. 5.4.2.2 (phosphoglucomutase, two loci: $P G M-1, P G M-$ 2), 6PGD E.C. 1.1.1.44 (6-phosphogluconate dehydrogenase, one locus: $6 P G D-1) S K D H$, E.C. 1.1.1.25 (shikimate dehydrogenase, one locus: $S K D H-1)$. Standard staining procedures $[2,28,39,42]$ were adapted with some minor modifications. Segregation analysis of polymorphic systems (Demesure and Le Guerroué, unpublished data) showed that these enzymes were encoded by 15 loci. The alleles were numbered from the fastest to the slowest.

\subsection{Data analysis}

Geographical variation of gene diversity and allele frequencies were tested in different ways. Several genetic diversity parameters were calculated, for all French populations, but also for each regional group. In addition, a comparison between the French populations and the Central European ones was carried out. Allele frequencies were calculated for each population and gene diversity parameters estimated on a within population basis. The number of alleles per locus $\left(N_{\mathrm{a}}\right)$ was calculated over all the loci, as well as Nei's genetic diversity indices $[26,27]$. Population differentiation can be summarised by $F$-statistics $\left(F_{\text {IS }}, F_{\mathrm{ST}}\right)$ as defined by Wright [44], for groups of populations [13]. The similarity between pairs of populations was measured by Nei's unbiased genetic distances corrected for small sample sizes [27]. Dendrograms were produced based on this distance using the UPGMA method [13]. All estimators of the parameters of interest (allele frequencies, genetic diversity and differentiation) were computed using POPGENE 1.2 [46]. Another useful parameter to evaluate differences in levels of diversity $H$ across populations is the coefficient of variation of $H$ (standard deviation of $H$ 
divided by the mean). One-way analysis of variance was used to investigate the difference between groups of populations, based on the parameters estimated in each individual population. For each parameter $\left(N_{\mathrm{a}}, H_{\mathrm{o}}, H_{\mathrm{e}}\right.$ and $\left.F_{\text {IS }}\right)$ considered, we therefore tested whether significant $(P<0.05)$ differences occurred among groups. For the comparison between France and Central Europe, standard errors of diversity parameters were based on the sampling of loci.

Multivariate analyses (factorial analysis) based on the presence or absence of each detected allele at each locus were also performed. For each allele in each individual, the data was coded as 2, 1 or 0 when the allele was observed in the homozygous condition, in the heterozygous condition or not observed, respectively. In order to assess the effect of geographical distances between populations on their genetic distances, multilocus genetic distances were computed between all pairs of populations, following Degen and Scholz [3]. All pairs of populations were then classified in ten geographic distance classes from 0 to $1000 \mathrm{~km}$, and the relationship between genetic and geographical distances was tested against the hypothesis of random spatial genetic structure by permutation analysis [3].

\section{RESULTS}

\subsection{Overall genetic variability of Sorbus torminalis in France}

Nine of the 15 loci were polymorphic in France (table II), with a range of 5 to 9 polymorphic loci in each population. The number of alleles per polymorphic locus ranged from 2 to 5 with a mean of 2.0. In France, the average of observed and expected heterozygosities were respectively 0.137 and 0.190 (table II). The $F_{\text {IS }}$ values were positive at six loci and negative at three other ones $(A D H, 6-P D H, I D H-1)$ : the combined value over all loci was 0.15 . The coefficient of differentiation among populations, $F_{\mathrm{ST}}$, ranged from 0.10 to 0.32 across loci, with an overall value of 0.15 (table $I I$ ). The coefficient of variation of $H$ across all 73 populations was 0.20 .

Most alleles were found throughout France. However, allele $e$ of $P G M-2$ was only observed in the Pyrénées (group 5) and allele $d$ of $A D H$ was restricted to north of France (group 1). In addition, allele $b$ of $A A P$ was absent in group 5 and allele $b$ of $S K D H$ was absent from group 1. The mean number of alleles per group (table III) varied very little: from 1.53 (group 6) to 1.60 (group 2), and no significant group effect was detected by the analysis of variance. Observed and expected heterozygosities ranged from 0.111 (group 6) to 0.154 (group 8), and from 0.130 (group 6) to 0.172 (group 4)
Table II. Genetic diversity estimates per locus among the French populations and the Central European ones. $N_{a}$, number of alleles per locus; $H_{0}$, observed heterozygosity; $H_{\text {, }}$, expected heterozygosity; $F_{\text {IS }}$, heterozygote deficit; $F_{\mathrm{ST}}$ differentiation coeficient; SD, standard deviation.

\begin{tabular}{|c|c|c|c|c|c|c|}
\hline France & Locus & $N_{\mathrm{a}}$ & $H_{\mathrm{o}}$ & $H_{\mathrm{e}}$ & $F_{\text {IS }}$ & $F_{\mathrm{ST}}$ \\
\hline & $\mathrm{ADH}$ & 4 & 0.421 & 0.473 & -0.00 & 0.11 \\
\hline & $\mathrm{ACP}$ & 1 & - & - & - & - \\
\hline & 6-PDH & 2 & 0.361 & 0.393 & -0.03 & 0.12 \\
\hline & PRX-1 & 2 & 0.102 & 0.296 & 0.56 & 0.24 \\
\hline & PRX-2 & 2 & 0.094 & 0.131 & 0.22 & 0.10 \\
\hline & ME & 3 & 0.488 & 0.647 & 0.15 & 0.11 \\
\hline & SKDH & 2 & 0.031 & 0.130 & 0.62 & 0.32 \\
\hline & AAP & 2 & 0.082 & 0.155 & 0.25 & 0.27 \\
\hline & IDH-1 & 2 & 0.099 & 0.106 & -0.04 & 0.11 \\
\hline & IDH-2 & 1 & - & - & - & - \\
\hline & PGM-1 & 1 & - & - & - & - \\
\hline & PGM-2 & 5 & 0.382 & 0.521 & 0.13 & 0.16 \\
\hline & MR-1 & 1 & - & - & - & - \\
\hline & MR-2 & 1 & - & - & - & - \\
\hline & GOT-2 & 1 & - & - & - & - \\
\hline & Mean & 2.0 & 0.137 & 0.190 & 0.15 & 0.15 \\
\hline & SD & 1.2 & 0.178 & 0.221 & & \\
\hline Central & & & & & & \\
\hline & $\mathrm{ADH}$ & 3 & 0.319 & 0.317 & -0.01 & 0.04 \\
\hline & $\mathrm{ACP}$ & 1 & - & - & - & - \\
\hline & 6-PDH & 2 & 0.291 & 0.288 & -0.15 & 0.07 \\
\hline & PRX-1 & 2 & 0.048 & 0.207 & 0.77 & 0.14 \\
\hline & PRX-2 & 2 & 0.022 & 0.029 & 0.41 & 0.02 \\
\hline & ME & 4 & 0.565 & 0.629 & 0.03 & 0.12 \\
\hline & SKDH & 2 & 0.026 & 0.047 & 0.40 & 0.05 \\
\hline & AAP & 2 & 0.008 & 0.030 & 0.60 & 0.03 \\
\hline & IDH-1 & 2 & 0.118 & 0.117 & -0.04 & 0.03 \\
\hline & IDH-2 & 1 & - & - & - & - \\
\hline & PGM-1 & 1 & - & - & - & - \\
\hline & PGM-2 & 5 & 0.428 & 0.529 & 0.13 & 0.06 \\
\hline & MR-1 & 1 & - & - & - & - \\
\hline & MR-2 & 1 & - & - & - & - \\
\hline & GOT-2 & 3 & 0.125 & 0.131 & -0.07 & 0.10 \\
\hline & Mean & 2.1 & 0.130 & 0.155 & 0.09 & 0.08 \\
\hline & SD & 1.2 & 0.411 & 0.203 & & \\
\hline
\end{tabular}

respectively. Here, the analysis of variance revealed significant differences among groups $\left(P=0.02\right.$ for $H_{0}$ and $P=0.01$ for $H_{\mathrm{e}}$ ). The mean within-population heterozygote deficit $\left(F_{\text {IS }}\right)$ ranged from 0.07 (group 7 ) to 0.28 (group 2), with no significant differences among groups. The coefficient of genetic differentiation $\left(F_{\mathrm{ST}}\right)$ was computed in each of the eight groups. It ranged from 0.08 in Brittany (group 3) to 0.15 in the southwest of France (group 4). 
Table III. Genetic diversity measures within the 8 French groups and the central European group.

\begin{tabular}{lccccc}
\hline Region & $N_{\mathrm{a}}$ & $H_{\mathrm{o}}$ & $H_{\mathrm{e}}$ & $F_{\text {IS }}$ & $F_{\text {ST }}$ \\
\hline Group 1 (SD) & $1.62(0.13)$ & $0.133(0.037)$ & $0.155(0.023)$ & $0.14(0.17)$ & 0.10 \\
Group 2 (SD) & $1.60(0.11)$ & $0.115(0.020)$ & $0.160(0.034)$ & $0.28(0.15)$ & 0.12 \\
Group 3 (SD) & $1.66(0.09)$ & $0.133(0.022)$ & $0.160(0.017)$ & $0.17(0.09)$ & 0.08 \\
Group 4 (SD) & $1.65(0.07)$ & $0.147(0.029)$ & $0.172(0.024)$ & $0.14(0.16)$ & 0.15 \\
Group 5 (SD) & $1.58(0.14)$ & $0.119(0.018)$ & $0.131(0.036)$ & $0.09(0.20)$ & 0.11 \\
Group 6 (SD) & $1.53(0.07)$ & $0.111(0.025)$ & $0.130(0.014)$ & $0.14(0.15)$ & 0.11 \\
Group 7 (SD) & $1.62(0.15)$ & $0.149(0.022)$ & $0.160(0.025)$ & $0.07(0.18)$ & 0.10 \\
Group 8 (SD) & $1.61(0.10)$ & $0.154(0.036)$ & $0.168(0.033)$ & $0.08(0.12)$ & 0.11 \\
Central Europe (SD) & $1.73(0.08)$ & $0.122(0.031)$ & $0.133(0.027)$ & $0.09(0.13)$ & 0.08 \\
\hline Overall mean (SD) & $1.63(0.10)$ & $0.134(0.031)$ & $0.156(0.030)$ & $0.13(0.15)$ & 0.15 \\
\hline
\end{tabular}

$N_{\mathrm{a}}$, number of alleles per locus; $H_{\mathrm{o}}$, observed heterozygosity; $H_{\mathrm{e}}$, expected heterozygosity; $F_{\mathrm{IS}}$, heterozygote deficit; $F_{\mathrm{ST}}$ differentiation coeficient; $\mathrm{SD}$, standard deviation.

\subsection{Comparison of French populations with central European populations}

Ten of the 15 loci were polymorphic in Europe (table II). The locus GOT-2 was polymorphic only in 3 populations (two in Slovakia and one in Bulgaria). One rare allele appears in the eastern European populations at the locus $M E$. There were no consistent differences between the French and the Central European populations groups (table III). It can be noticed that the number of alleles is slightly higher (2.1) and the value of the $F_{\mathrm{ST}}$ (0.08) lower for the eastern European populations than for the French populations (table II). However, the analysis of variance based on the differences across loci did not detect any significant differences between the French populations and Central European ones.

\subsection{Geographic structuring of the diversity in France}

The UPGMA dendrogram using Nei's unbiased distance (figure 2) did not reveal any clustering of geographically close populations. A multivariate analysis indicates the same lack of geographic structure (data not shown). However, the analysis of the correlation between Nei's genetic distances and geographic distances revealed a slight but significant positive relationship at distances up to $120 \mathrm{~km}$ (figure 3).

\section{DISCUSSION}

Our results for the wild service tree are consistent with those obtained for allozyme markers in most forest trees studied to date: little differentiation among popula- tions and a comparatively high level of genetic diversity. The estimates of genetic variation at the species level that we obtained in $S$. torminalis $(P=66 \%, A=2.20$, $\left.H_{\mathrm{e}}=0.185\right)$ were very close to those obtained by Hamrick et al. [11] in long-lived woody perennials $\left(P=65 \%, A=2.22, H_{\mathrm{e}}=0.177\right)$. Similarly, at the within population level, results for $S$. torminalis $(P=57 \%$, $\left.A=1.62, H_{\mathrm{e}}=0.156\right)$ are very close to those of the other trees $\left(P=49 \%, A=1.76, H_{\mathrm{e}}=0.148\right)$. The diversity values for $S$. torminalis are however lower than those obtained by Raspé et al. for Sorbus aucuparia in Europe [33] within population $\left(P=63 \%, A=2.25, H_{\mathrm{e}}=0.212\right)$ and within species $\left(P=90 \%, A=3.70, H_{\mathrm{e}}=0.229\right)$. The difference observed between the two species may be explained by ecological differences and postglacial history. Indeed Sorbus aucuparia grows in relatively wet and cool climate, consequently it is confined to mountain areas in the southernmost part of its range, and it can be found at high latitudes. On the other hand, Sorbus torminalis is found in drier habitats, in the plains at lower latitudes, and is absent at high altitudes. Hence, it is likely that during the last ice-age the climate was more adapted to Sorbus aucuparia which could persist in numerous small populations in glacial refugia, and maintain higher levels of diversity. Our results for $S$. torminalis indicate that the genetic diversity is equally distributed in France. No strong differences can be noted for the mean number of alleles per population. The coefficient of variation of $H(0.20)$ is only slightly larger than that observed in a compilation of 62 outcrossing tree species (0.17) (R.J. Petit, in prep.), indicating that levels of diversity are not especially heterogeneous. Although still small compared to herbaceous species, the observed $F_{\mathrm{ST}}$ value $(0.15)$ is however higher than that reported in other forest tree species (e.g., $F_{\mathrm{ST}}=0.06$ for $S$. aucuparia, [33]; 


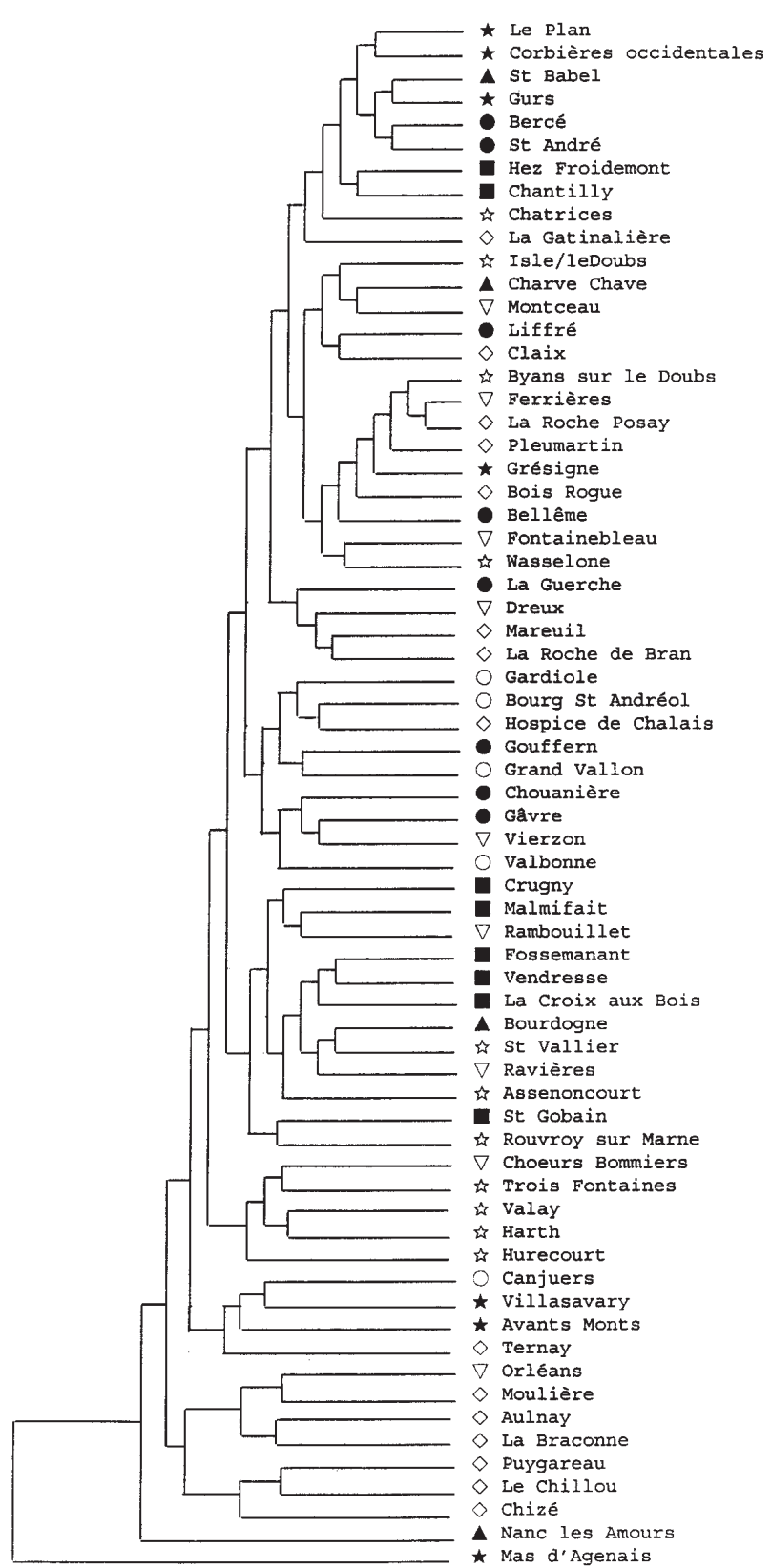

Fig. 2. UPGMA clustering of 67 populations of Sorbus torminalis based on Nei's genetic distance.

$F_{\mathrm{ST}}=0.03$ for Quercus petraea, [47]; $F_{\mathrm{ST}}=0.05$ for Prunus avium, [6]). It is also of comparable magnitude to the estimate obtained Prat \& Daniel in a previous more limited study of the species $\left(F_{\mathrm{ST}}=0.10\right)$ [29]. According to Hamrick et al. [11], the mean $F_{\mathrm{ST}}$ for trees with animal-dispersed seeds (0.05) is much lower than

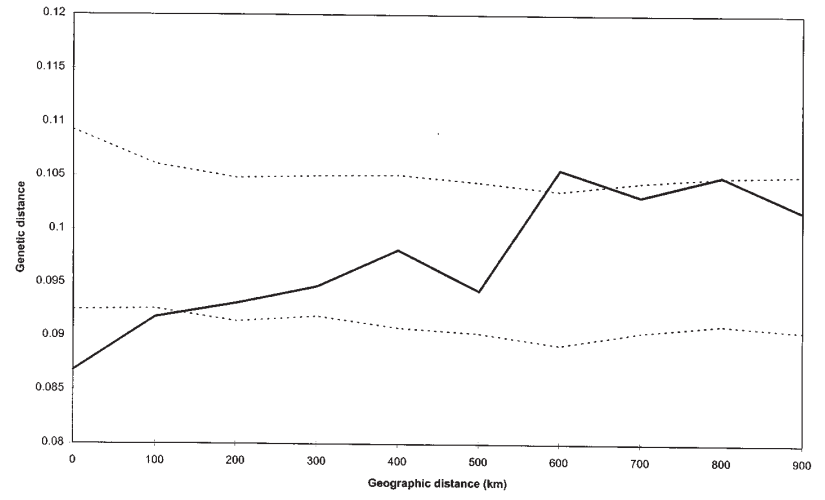

Fig 3. Genetic distogram (genetic distances versus geographic distances) for 9 distance classes $(0-900 \mathrm{~km})$, and $95 \%$ confidence intervals of the genetic distance, computed by means of 1000 permutations.

the value observed in Sorbus torminalis. Interestingly, other authors have also reported relatively high $F_{\mathrm{ST}}$ values for scattered species having small populations: 0.33 for Ulmus laevis [23], 0.18 for Ulmus minor [21], 0.13 for Acer platanoides [34], 0.13 for Ocotea tenera [7], 0.20 for Alnus glutinosa [30]. Allozyme studies show clearly that population subdivision promotes differentiation: values of $F_{\mathrm{ST}}$ are higher in subdivided than in continuous habitats [1, 31]. Most disseminated tree species are not randomly mating, due to their scattered distribution and pollination by vectors which fly over short distances only [19]. Therefore genetic drift can have a great importance in their evolution. Although Sorbus torminalis seems to be mainly outcrossing, as suggested by the small heterozygote deficit in the populations, a rapid divergence between populations can appear. The high $F_{\text {ST }}$ value can also be explained by founder effects. Indeed, $S$. torminalis is a nomad species and its populations have a rapid turnover. Theoretical studies have shown that founding events may increase differences between young populations, depending notably on the number of individuals involved in the founding events and the number of source populations from wich they are drawn [41].

Hence, the major result of this study is the combination of the relatively high $F_{\mathrm{ST}}$ and the weak geographic structure. The distogram indicates that populations separated by less than $150 \mathrm{~km}$ are more related than those further apart, but the other analyses have failed to detect any geographic structure at the monolocus level. Paradoxically, some comparable studies in forest trees have found low $F_{\mathrm{ST}}$ values combined with a strong geographic structure at the multilocus level [16] or even at 
the monolocus level [17]. Studies of the genetic consequences of population dynamics within a forest but also over a larger scale, will be necessary to clarify this finding in order to examine how populations are interconnected by gene flow. Sorbus torminalis is distributed all over France except in the mountains and it is possible that this species functions in metapopulations. Indeed, as a nomad species, $S$. torminalis populations can be defined as a set of subpopulations in which the individual demes are subject to frequent local extinction, but may be replaced through colonisation $[12,18]$. This definition could apply well to the dynamics of the wild service tree. Recently there has been a considerable interest in the genetic properties of metapopulations, particularly on the influence of the frequent extinction and colonisation events on the maintenance of genetic variation and on the partitioning of this variation within and among local populations $[8,25,36]$. Extinction and recolonisation may produce a certain amount of genetic differentiation through founder effects, if the groups that found the new populations are sufficiently small and homogeneous [37, 41, 43]. McCauley et al. [24] have shown that a set of recently founded populations of Silene alba displays considerable genetic differentiation and this structure can be ascribed to a mode of colonisation in which there is only limited mixing of individuals from different sources.

Although further investigations will be necessary to understand in more details the population genetics of Sorbus torminalis, the results of our investigation can already contribute to a more rationale management of the genetic resources of this scattered and valuable tree species. Indeed, if the species does function as a metapopulation, local extinction and colonisation are expected in the forest. So the manager must take care to leave free areas in the forest that can be colonised by new populations of wild service tree. This implies for example local absence of social tree species and a special care during the seedling development. Because gene flow is naturally important, as evidenced from the weakness of geographic structure at the studied scale, maintenance of conditions favouring high gene flow are essential; in particular, animal dispersers (insects and birds) should be preserved. The birds and especially the thrushes (Turdus sp.) seem to play an important role in the homogenisation of the genetic structure over large distances. Indeed the fruits of wild service tree are mature during the migration of the birds, in autumn. The development of maternally inherited cytoplasmic markers in Sorbus torminalis will also give more information on the number and origin of founder trees, when new populations become established.
Acknowledgements: We would like to thank the numerous technicians of the French National Forest Office, as well as D. Gömory, R. Longauer, P. Rotach, V. Hynek, R. Brus and P. Jevel who collected the Sorbus samples. This study has been partly supported by the Conseil Régional of Poitou-Charentes. We also thank B. Roman-Amat and M. Vallance for their useful comments on the manuscript.

\section{REFERENCES}

[1] Ayers D.J., Dufty Y.S., Evidence for restricted gene flow in a viviparous coral Seriatopara hystrix on Australia's Great Barrier Reef, Evolution 4 (1994) 1183-1201.

[2] Cheliak W.M., Pitel J.A., Techniques d'électrophorèse sur gel d'amidon des enzymes d'essences d'arbres forestiers, Canadian Forest Service, Petawawa National Forest institute, Chalk river, Information Report PI-X-42F (1986).

[3] Degen B., Scholz F., Spatial genetic differentiation among populations of European beech (Fagus sylvatica L.) in western Germany as identified by geostatistical analysis, Forest Genetics 5 (1998) 191-199.

[4] Doligez A., Baril C., Joly H., Fine-scale spatial genetic structure with non-uniform distribution of individuals, Genetics 148 (1998) 905-919.

[5] Drapier N., Écologie de l'alisier torminal, Sorbus torminalis (L.) Crantz, Revue Forestière Française 3 (1993) 229-243.

[6] Frascaria N., Santi F., Gouyon P.H., Genetic differentiation within and among populations of chestnut (Castanea sativa Mill.) and wild cherry (Prunus avium L.), Heredity 70 (1993) 634-641.

[7] Gibson P.J., Wheelwright N.T., Genetic structure in populations of a tropical tree Ocotea tenera (Lauraceae): influence of avian seed dispersal, Oecologia 103 (1995) 49-54.

[8] Gilpin M.E., The genetic effective size of metapopulation, Biol. J. Linn. Soc. 42 (1991) 165-175.

[9] Godron D.A., De l'hybridité dans le genre Sorbier, Revue des Sciences Naturelles 4 (1874) 443-447.

[10] Hamrick J.L., Godt M.J.W., Allozyme diversity in plant species, in AHD Brown M.T., Clegg A.L., Kahler and Weir B.S. (Eds.), Plant population genetics, breeding and genetic resources. Sinauer, Sunderland, Massachusetts, 1989, pp. 43-63.

[11] Hamrick J.L., Godt M.J.W., Sherman-Broyles S.L., Factors influencing levels of genetic diversity in woody plant species, New Forests 6 (1992) 95-124.

[12] Hanski I., Gilpin M., Metapopulation dynamics - brief history and conceptual domain, Biol. J. Linn. Soc. 42 (1991) 3-6.

[13] Hartl D.L., Clark A.G., Principles of population genetics. 2nd ed. Sinauer Associates, Sunderland, Massachusetts (1989).

[14] Karron J.D., A comparison of levels of genetic polymorphism and self-compatibility in geographically restricted 
and widespread plant congeners, Evolutionary Ecology 1 (1987) 47-58.

[15] Karron J.D., Linhart Y.B., Chaulk C.A., Robertson C.A., Genetic structure of populations of geographically restricted and widespread species of Astragalus (Fabaceae), Amer. J. Bot. 75 (1988) 1114-1119.

[16] Kremer A., Zanetto A., Geographical structure of gene diversity in Quercus petraea (Matt.) Liebl. II: Multilocus patterns of variation, Heredity 78 (1997) 476-489.

[17] Leonardi S., Menozzi P., Genetic variability of Fagus sylvatica L. in Italy: the role of postglacial recolonization, Heredity 75 (1995) 35-44. 75-107.

[18] Levins R., Extinction, Lect. Math. Life Sci. 2 (1970)

[19] Levin D.A., Kerster H.W., Gene flow in seed plants. Evol. Biol. 7 (1974) 139-220.

[20] Liljefors A., Cytological studies in Sorbus, Acta Horti Bergiani 17 (1955) 47-113.

[21] Machon N., Lefranc M., Bilger I., Mazer S.J., Saar A., Allozyme variation in Ulmus species from France: analysis of differentiation, Heredity 78 (1997) 12-20.

[22] Marriette S., Lefranc M., Legrand P., Taneyhill D., Frascaria-Lacoste N., Machon N., Genetic variability in wild cherry populations in France. Effects of colonizing processes, Theor. Appl. Genet. 94 (1997) 904-908.

[23] Mattila A., Vakkari P., Genetic variation of Quercus robur and Ulmus laevis in Finland. In Proc. Nord. Meet. For. Genet. Tree Breeders, Estonia, 1997, pp. 63-68.

[24] Mc Cauley D.E., Raveill J., Antonovics J., Local founding events as determinants of genetic structure in a plant metapopulation, Heredity 75 (1995) 630-636.

[25] Muruyama T., Kimura M., Genetic variability and effective population size when local extinction and recolonization of subpopulations are frequent, Proc. Natl. Acad. Sci. USA 77 (1980) 6710-6714.

[26] Nei M., Analysis of gene diversity in subdivided populations, Proc. Natl. Acad. Sci. USA 70 (1973) 3321-3323.

[27] Nei M., Estimation of average heterozygosity and genetic distance from a small number of individuals, Genetics 89 (1978) 583-590.

[28] Pasteur N., Pasteur G., Bonhomme F., Catalan J., Britton-Davidian J., Manuel technique de génétique par électrophorèse des protéines, Technique et Documentation Lavoisier, Paris, 1987.

[29] Prat D., Leger C., Bojovic S., Genetic diversity among Alnus glutinosa (L.) Gaertn. Populations, Acta Oecologica 13 (4) (1992) 469-477.

[30] Prat D., Daniel C., Variabilité génétique de l'alisier torminal et du genre Sorbus, Rev. For. Fr. 3 (1993) 216-229.

[31] Preziosi R., Fairbairn D.J., Genetic population structure and levels of gene flow in the stream-dwelling water strider Aquarius (Gerris) remigis (Hemiptera: Gerridae), Evolution 46 (1992) 430-444.
[32] Purdy B.G., Bayer R.J., Allozyme variation in the Athabasca sand dune endemic, Salix silicicola, and the closely related widespread species, $S$. alaxensis, Systematic Botany 20 (2) (1995) 179-190.

[33] Raspé O., Jacquemart A.L., Allozyme diversity and genetic structure of European populations of Sorbus aucuparia, Heredity 81 (5) (1998) 537-545.

[34] Rusanen M., Mattila A., Vakkari P., Jalojen lehtipuden geneettinen monimuotoisuus-säyliytä ja käytä, Metsänt Tied. 605 (1996) 45-52.

[35] Schirenbeck K.A., Skupski M., Lieberman D., Lieberman M., Population structure and genetic diversity in four tropical tree species in Costa Rica, Molecular Ecology 6 (1997) 137-144.

[36] Schoen D.J., Brown A.H.D., Intraspecific variation in population gene diversity and effective population size correlates with the mating system in plants, Proc. Natl. Acad. Sci. USA 88 (1991) 4494-4497.

[37] Slatkin M., Gene flow and genetic drift in a species subject to frequent local extinction, Theor. Pop. Biol. 12 (1977) 253-262.

[38] Soltis P.S., Soltis D.E., Trucker T.L., Lang F.A., Allozyme variability is absent in the narrow endemic Bensoniella oregona ( Saxifragaceae), Conservation Biology 6 (1992) 131-134.

[39] Vallejos C.E., Enzyme activity staining. In: Isoenzymes in plants genetics and breeding, part. Tanksley S.D., Orton T.J. (Eds.), A. Elsevier Sci Publ, Amsterdam, 1983, pp. 469-516.

[40] Vicario F., Vendramin G.G., Rosi P., Liò P., Giannini, Allozyme, chloroplast DNA and RAPD markers for determining genetic relationships between Abies alba and relic population of Abies nebrodensis, Theor. Appl. Genet. 90 (1995) 10121018.

[41] Wade M.J., McCauley D.E., Extinction and recolonization: their effects on the genetic differentiation of local populations, Evolution 42 (1988), 995-1005.

[42] Wendel J.F., Weenden N.F., Visualization and interpretation of plant isozymes. In Isozymes in plant biology, Soltis D.E., Soltis P.S. (Eds.), Discorides Press, Portland, 1989, pp. 5-45.

[43] Whitlock M.C., Mc Cauley D.E., Some population genetic consequences of colony formation and extinction: genetic correlations within funding groups, Evolution 44 (1990) 1717-1724.

[44] Wright S., The genetical structure of populations, Annals of Eugenics 15 (1951) 323-354.

[45] Yagihashi T., Hayashida M., Miyamoto T., Effects of bird ingestion on seed germination of Sorbus commixta, Oecologia 114 (1998) 209-212.

[46] Yeh F., Boyle T., PPOGENE 1.2, Microsoft windowbased Software for population genetic analysis, 1997.

[47] Zanetto A., Kremer A., Geographical structure of gene diversity in Quercus petraea (Matt.) Liebl. I. Monolocus patterns of variation, Heredity 75 (1995) 506-517. 